\title{
Landscape terms and place names in the Trobriand Islands - the Kaile'una subset
}

\author{
Gunter Senft * \\ Max Planck Institute for Psycholinguistics, Language and Cognition, PB 310, 6500 AH Nijmegen, Netherlands
}

\begin{abstract}
After a brief introduction to the topic the paper first gives an overview of Kilivila landscape terms and then presents the inventory of names for villages, wells, island points, reef-channels and gardens on Kaile'una Island, one of the Trobriand Islands in the Milne Bay Province of Papua New Guinea. The data on the meaning of the place names presented were gathered in 2004 with six male consultants (between the age of 36 and 64 years) living in the village Tauwema on Kaile'una Island. Thus, the list of place names is quite possibly not the complete sample, but it is reasonably representative of the types of Kilivila place names. After discussing the meaning of these terms the paper presents a first attempt to typologically classify and categorize the place names. The paper ends with a critical discussion of the landscape terms and the proposed typology for place names.

(C) 2006 Elsevier Ltd. All rights reserved.
\end{abstract}

Keywords: Landscape terms; Place names; Kilivila; Trobriand Islands; Kaile'una Island; Papua New Guinea

...the landscape represent[s] a continuous story... (Malinowski, 1922, p. 298)

\section{Introduction}

I first hit upon landscape terms and place names in 1978 when I started the literature search for my Ph.D. thesis on the language variety of workers of my hometown (Senft,

\footnotetext{
* Tel.: +31 243521 911; fax: +31243521300.

E-mail address: Gunter.Senft@mpi.nl
} 
1982). I found many publications on landscape terms and place names in that area (see e.g. Christmann, 1937a,b, 1938, 1940, 1968) and I learned that German dialectology and toponymy developed into scientific disciplines roughly at the same time. One of the first landmarks in German toponomy was Förstemann's (1863) monograph on German place names; Bach's œuvre on German toponomy, the second enlarged edition of which was published between 1952 and 1954, still constitutes one of the most important reference books in the field. The discipline is still flourishing in Germany (see e.g. Schützeichel, 1985; Ernst et al., 2002; Urmes, 2004). It is interesting to note that German research on landscape terms and place names has always closely cooperated not only with dialectology, but also with history, geography, sociology, folklore, and psychology (as can be seen in the subtitles of Bach's volumes).

It is interesting to note that the German scholar Franz Boas, who finished his studies in Berlin with his 'Habilitation' on Baffin Island as a 'Privatdozent' in geography, became not only the 'father' of American anthropology but also one of the founding fathers of toponomy in the United States. As early as 1934 Boas - with his publication on the geographical names of the Kwakiutl Indians - had established toponomy as an important co-discipline of anthropology. He was one of the scientists of the late 19th and early 20 th century who realized the importance of this discipline for multidisciplinary oriented anthropological and linguistic research, and he founded a tradition within American anthropology that is also still active (see, e.g. Lounsbury, 1960; Basso, 1984; Mithun, 1984; Bright, 1998a,b, 2004; Hunn, 1996; Cowell and Moss, 2003). ${ }^{1}$ Research on place names in the vein of scholars like Förstemann, Bach, and Boas is done worldwide these days (see e.g., Broderick, 1994, 1995, 1997, 1999, 2000, 2002, 2005; Dominy, 1995; Hercus et al., 2002; Hosokawa, 2003; Kari, 1989; Marck, 1994; see also Tindale, 1962). However, the discipline is also open for innovative developments. Thus, just a few years ago a new field of study - geographical ontology - was established by researchers like David Mark, Barry Smith, and Andrew Turk (see e.g., Mark and Turk, 2003; Smith and Mark, 1999, 2001).

This paper aims to contribute to the research of landscape terms and place names in Oceania. In what follows I will first provide some general information about the Trobriand Islands, about the Trobriand Islanders and about their language Kilivila. Then I will give an overview of Kilivila landscape terms and present names for villages, wells, island points, reef-channels and gardens on Kaile'una Island, one of the Trobriand Islands in the Milne Bay Province of Papua New Guinea. After discussing the meaning of these terms I present a first attempt to typologically classify and categorize the place names. The paper ends with a critical discussion of the proposed typology.

\section{The Trobriand Islands, the Trobriand Islanders and their language}

The Trobriand Islands, a group of about 20 islands and islets, are situated at the $151.04^{\circ}$ of Eastern Longitude and $8.38^{\circ}$ of Southern Latitude in Milne Bay Province, Papua New Guinea. Kitava Island is an elevated coral island which rises to about $30 \mathrm{~m}$ at a central ridge. The other islands and islets are low-lying flat coral atolls. All islands

\footnotetext{
${ }^{1}$ I would like to note here that since 1998 Bill Bright has a column called 'The place department' in the Newsletter of The Society for the Study of the Indigenous Languages of the Americas (SSILA).
} 
are coral formations composed of coralline limestone. Most of them are fringed by coral reefs. The islands Kitava, Kiriwina, Vakuta, Kaile'una, Muwa, Kuiawa, Munuwata, Tuma, and Simsim are populated. The islands are considered to be an important tropical rainforest eco-region.

The Trobriand Islanders have become famous, even outside of anthropology, because of the ethnographic masterpieces on their culture published by the famous anthropologist Bronislaw Kaspar Malinowski, who did field research there between 1916 and 1920 (see Young, 2004; also Senft, 1999). The Trobrianders belong to the ethnic group called 'Northern Massim'. They are gardeners, doing slash and burn cultivation of the bush; their most important crop is yam. Moreover, they are famous for being excellent canoe builders, carvers, and navigators, especially in connection with the ritualized Kula trade, an exchange of shell valuables that covers a wide area of the Melanesian part of the Pacific (see Malinowski, 1922). The society is matrilinear but virilocal.

Kilivila, the language of the Trobriand Islanders, is one of 40 Austronesian languages spoken in the Milne Bay Province of Papua New Guinea. It is an agglutinative language and its general unmarked word order pattern is VOS (Senft, 1986). The Austronesian languages spoken in Milne Bay Province are grouped into 12 language families; one of them is labeled Kilivila. The Kilivila language family encompasses the languages Budibud (or Nada, with about 200 speakers), Muyuw (or Murua, with about 5000 speakers) and Kilivila (or Kiriwina, Boyowa, with about 25,000 speakers); Kilivila is spoken on the populated islands mentioned above. The languages Muyuw and Kilivila are each split into mutually understandable local dialects. Typologically, Kilivila is classified as a Western Melanesian Oceanic language belonging to the 'Papuan-Tip-Cluster' group (Ross, 1988, p. 25, pp. 190ff; Senft, 1986, p. 6).

\section{Landscape terms and place names on Kaile'una}

After I had finished my Ph.D. in 1982 I started research on the language and culture of the Trobriand Islanders. One of my research aims was to write a grammar and a dictionary of Kilivila. My lexicographic work revealed that it was relatively easy to get information about landscape terms. I also heard, learned and noted down a number of place names. However, whenever I asked my consultants about the meaning of these place names they told me that they did not know anything about it. There was only one exception - one of my consultants told me a story that goes with a place name which refers to a reef formation close to Tauwema, my village of residence on Kaile'una Island (see Senft, 1995). After a few more years and fieldtrips during which I tried in vain to get any further information on the meaning of place names, I had actually given up this subproject of my research. However, during my 2004 fieldtrip I wanted to at least document the named places I knew on a proper map. On the 22nd of July Mokeilobu (64 years old), Taidyeli (57 years old), Moagava (41 years old), Kwelava (36 years old), Kalavatu (51 years old), Bulasa (65 years old) and Mobiliuya (62 years old) were sitting on the veranda of my house, smoking and gossiping. When I asked them whether they would like to help me document place names on my map, ${ }^{2}$ they immediately agreed - and I was absolutely

\footnotetext{
${ }^{2}$ For the documentation of the place names and landscape terms I used a number of xerox copies of the following map: Kiriwina, Papua New Guinea, Scale: 1: 250 000, Series 1501, Sheet SC 56-1, Edition 1, printed by the Royal Australian Survey Corps Dec 1981. The figures presented in this paper are based on this map.
} 
flabbergasted when they asked me whether I would also like to know anything about the meaning of these names. ${ }^{3}$

In what follows I will first present the Kilivila landscape terms that I managed to document and then I will present the Kilivila place names and their meanings which I gathered with the six male consultants mentioned above. They all live in the village Tauwema on Kaile'una Island. I am almost certain that the list of place names presented and discussed is not complete, but it is reasonably representative of the types of place names to be found in Kilivila.

I present the Kilivila landscape terms in an order that seems to be appropriate to me keeping in mind that the speakers of this language are islanders. Thus, I start with terms for the sea, sea areas, currents, rivers and other bodies of water - i.e. with hydrology terms, and then present the terms that refer to the coral reefs, islands and to landscapes on the islands (or elsewhere), i.e. the geomorphology, pedology and biogeography terms. ${ }^{4}$ However, first of all I will briefly discuss the general Kilivila concept of valu.

The term valu is a semantically very general noun meaning something like 'place' or 'area' as in kosi la valu '(the) ghost's place (literally: ghost its place)'.

However, in specific contexts it can also be glossed as:

$\begin{array}{ll}\text { 'village' } & \text { as in valu Tauwema - '(the) village Tauwema' } \\ \text { 'town' } & \text { as in valu Alotau - '(the) town Alotau' } \\ \text { 'city' } & \text { as in valu Port Moresby - '(the) city (of) Port Moresby' } \\ \text { 'country' } & \text { as in valu Diyapani - '(the) country Japan' } \\ \text { 'continent' } & \text { as in valu Amelika - '(the) continent America' } \\ \text { 'world' } & \text { as in valu valu kumwedona - literally 'place place all' } \\ \text { or in valu vatanavalotanava - literally 'place on (the) ground' } \\ \text { as in valu katitekina Alotau - literally 'place(s) near Alotau' } \\ \text { 'landscape/ } \\ \begin{array}{l}\text { environment' } \\ \text { 'weather/climate' }\end{array}\end{array}$

Moreover, it is also used in the Trobriand expression for 'map' - kekwabula valu, literally 'picture/drawing its place'.

\subsection{The sea, sea areas, currents, rivers and other bodies of water}

The Kilivila terms for 'sea' consist of the hyperonym bwalita, a noun that refers to the sea in general, and the following phrases that refer to specific areas of it:

omamala literally 'at low tide' 'shallow sea between the beach and the inner reef'

This prepositional phrase consists of the locative $o$ and the noun mamala 'low tide'. It refers to the shallow waters area between the beach and the inner reef at low tide. There is no special name for this area at high tide.

\footnotetext{
${ }^{3}$ The fact that all seven consultants agreed on the meanings they provided for the place names indicates that the explanations were not made up on the spot (see also Malinowski, 1922, p. 40, 44, 298, pp. 330ff.; Senft, 1995, pp. 21f.).

${ }^{4}$ Kilivila landscape terms and place names are printed in italics, Kilivila place names are written with a capital initial.
} 
o tulupwaka

literally 'at white'

'sea between the inner and the outer reef'

This prepositional phrase consists of the locative $o$ and the nominalized contracted form of the colour term adjective pupwakau 'white'. It refers to that part of the sea between the inner and the outer reef where the water gets white after the waves break at the outer reef.

omata sulusulu literally 'in front of the boiling' 'sea that covers the outer reef'

This prepositional phrase consists of the locative omatala 'in front of' and the nominalised form of the verb -sulusulu- 'to cook', 'to boil'. It refers to the sea that covers the outer reef. At the drop-off of the outer reef the water seems to boil when the waves first break there.

omata takivi literally 'in front of the cut' 'sea between the drop-off

of the outer reef and the deep sea'

Once again, this term can be analysed as a prepositional phrase consisting of the locative omatala 'in front of' and the nominalised form of the verb -takivi- 'to cut'. It refers to the sea area where the outer reef drops off and the deep sea starts.

o tulubwabwau

literally 'on the deep dark sea'

'deep dark sea'

This term can once more be analysed as a prepositional phrase consisting of the locative $o$ and the noun tulubwabwau 'deep dark sea'. This form as well as the noun vivitu 'dark sea' refer to the deep, generally dark blue sea.

It is obvious that these terms represent a taxonomy that is based on the areas between the beach, the inner and the outer reef, the reef break-off and the deep sea. These areas are associated with other perceptual features like depth, colours and other observable qualities, which may also play a role in meaning.

Fig. 1 shows the extension of these sea areas for Kaile'una Island, and Fig. 2 does this for all of the Trobriand Islands. ${ }^{5}$ These figures were drawn by Moagava. When he was a very young boy his father Nusai started to take him with him and his small crew on his travels around the Trobriand Islands. Moagava did these sailing trips onboard his father's big masawa type canoe for many years and learned how to sail and to navigate. He drew the figures on the basis of this experience. He carefully chose five different coloured pencils out of a set of 18 pencils with different blue and green shades.

Fig. 3 presents the general currents in the sea surrounding the Trobriand Islands. These currents change their direction by day and by night, due to the tidal changes. The general Kilivila name for 'current' is yelu. However, the specific currents around the Trobriand Islands that are marked on the map are called Dam, and the current in the channel between Kaile'una and Kiriwina Island is called Dum. My consultants refer both expressions to, and explain them with, the utterance edumdumsi kesa' $i$ 'they (break and) beat the waves', i.e. 'the current(s) where the waves break and beat'.

\footnotetext{
${ }^{5}$ I would like to thank Alex Dukers for transforming the original drawings and my notes on the maps into printable figures.
} 

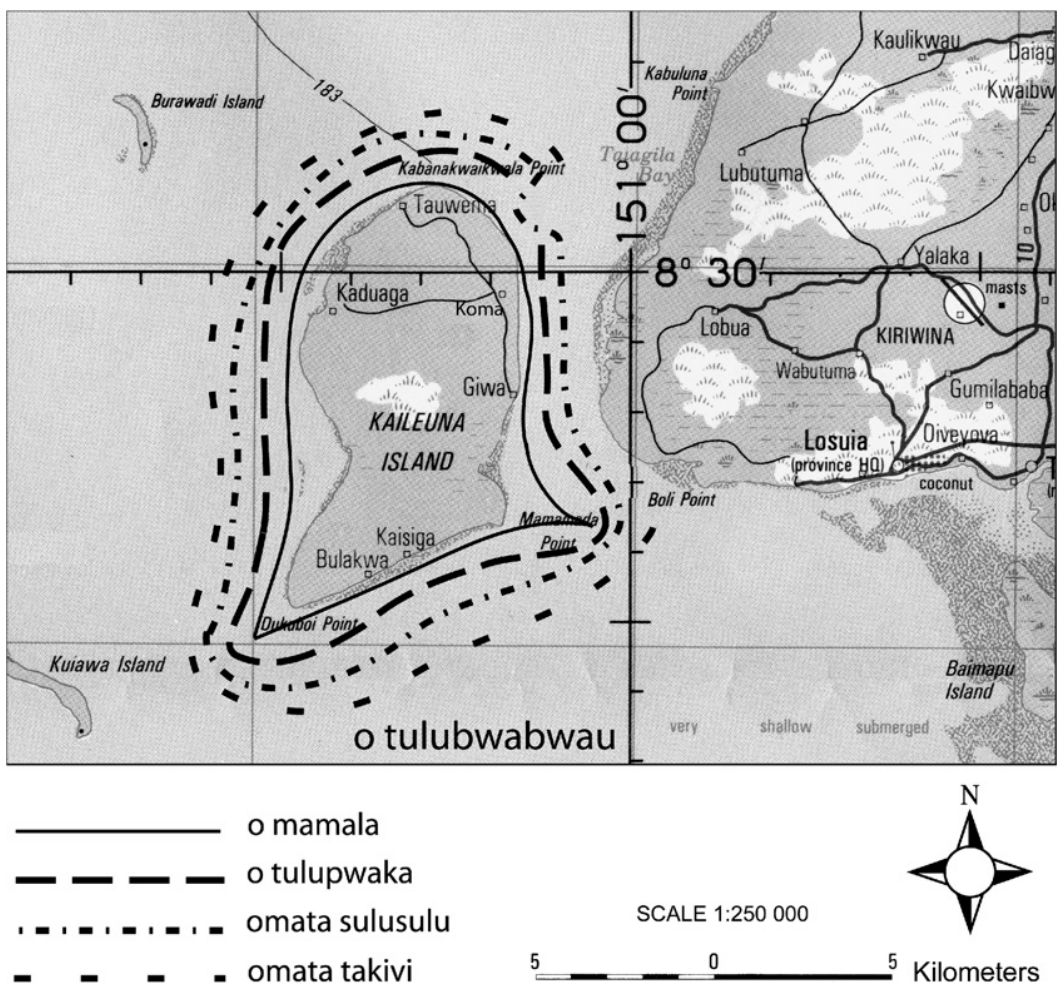

Fig. 1. Extension of sea areas for Kaile'una Island.

Fig. 4 presents the named parts of the sea around the Trobriand Islands that all my consultants mentioned during my interview with them. The sea area in the southwest of the Trobriand Islands that covers the area between the western shores of Vakuta and Kiriwina Island up to Boli point (of Kiriwina), the southern shores of Kaile'una, the northern point of Munuwata Island and the sea current Dam around the Islands is called Sasani 'rattles'. The name may have onomatopoeic connotations.

The strip-like area between Dukuboi point of Kaile'una and Kaduwaga ${ }^{6}$ village on Kaile'una Island that covers the uninhabited islands Labi and Nakwabi and ends at the current around the Trobriands is called Kugwa 'first'. My consultants do not know why this area was given this name.

The area above the northern border of the Kugwa part of the sea is called Kaunumayola. It covers the area between Kaduwaga village and Kabulukwevala ${ }^{7}$ point on Kaile'una Island and stretches to the northeast along the eastern coast of Bwemwaga ${ }^{8}$ and Tuma

\footnotetext{
${ }^{6}$ Fig. 8 presents the map of Kaile'una with the names of the villages. Note that the name of the village is spelled Kaduaga on the map. However, Kaduwaga is the proper Kilivila name of this village - and represents its proper spelling.

${ }^{7}$ Note again that the name of this point is spelled Kabanakwaikwala on the map. However, Kabulukwevala is the proper Kilivila name of this point these days.

${ }^{8}$ Note again that the name of this island is spelled Boimaga Island - and the name of the island south of Bwemwaga is spelled as Burawadi Island on the map. However, the proper Kilivila name of these islands is Bwemwaga and Buliwada:
} 


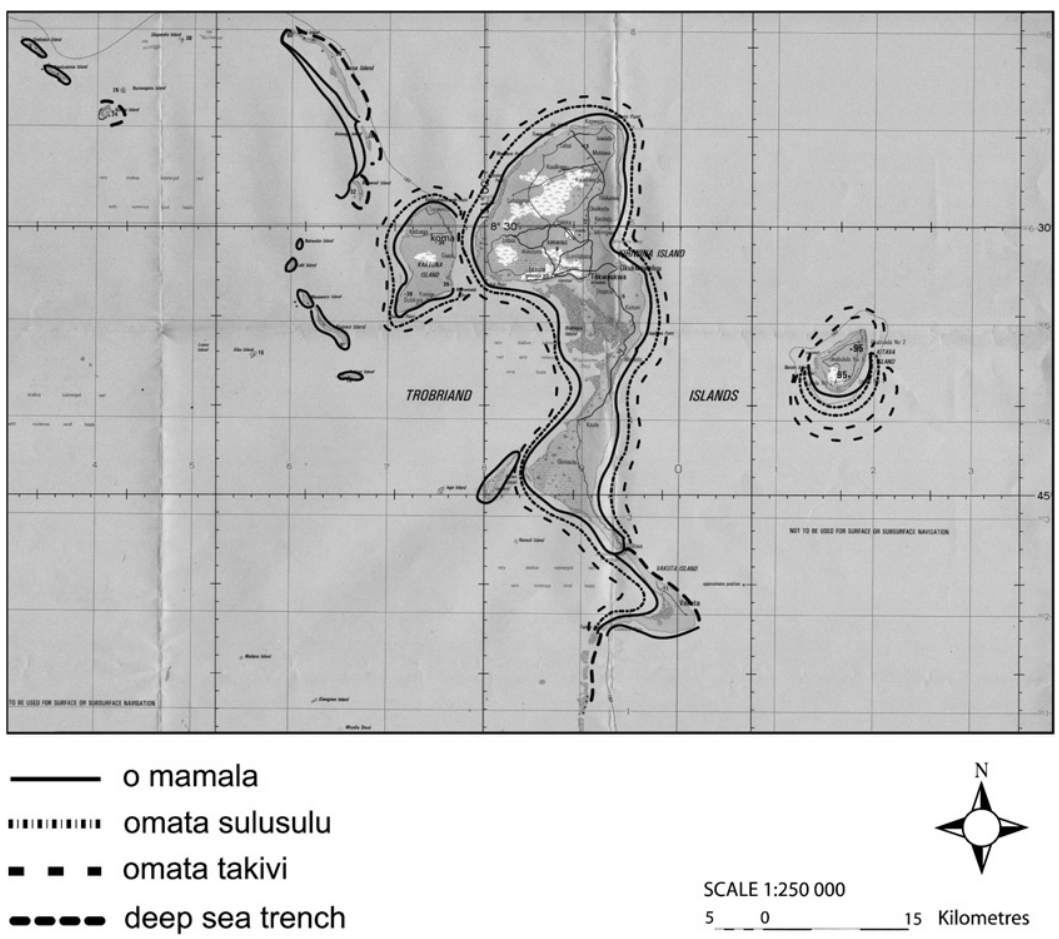

Fig. 2. Extension of sea areas for all of the Trobriand Islands.

Islands to the sea current around the Trobriands, but then extending to the west and covering the area north of Simsim Island. ${ }^{9}$ My consultants told me that the name Kaunumayola is an archaic variant of the word kaduvanogwa 'very old'. Again, they have no idea why this area was given this name.

The area that covers the channel between Kaile'una and Kiriwina Island, and stretches from the parts east of Kabulukwevala point on Kaile'una Island to Bomatu point at the north of Kiriwina Island, is called Kaulakoki. My consultants explain this name with the expression kaula o $k i$ 'food oh indeed', but they do not know why this area was named like this.

Finally, the area that covers the sea from the south-western point of Vakuta Island and between the eastern shores of Kiriwina Island and the western shores of Kitava Island up to Bomatu point on the northern tip of Kiriwina is called Dauya. My consultants explain this name as a variant of the noun tauya 'snail trumpet' (i.e. triton shells, Charonia tritonis) and refer to the fact that triton shells can be found in that area. All other parts of the sea are just referred to as bwalita 'sea'. My consultants are well aware that the English geographic name of this part of the Pacific is Solomon Sea. However, they hardly ever use this name if they refer to the sea.

\footnotetext{
${ }^{9}$ Note again that the name of this island is spelled Simlindon Island on the map. However, the proper Kilivila name of this island is Simsim.
} 


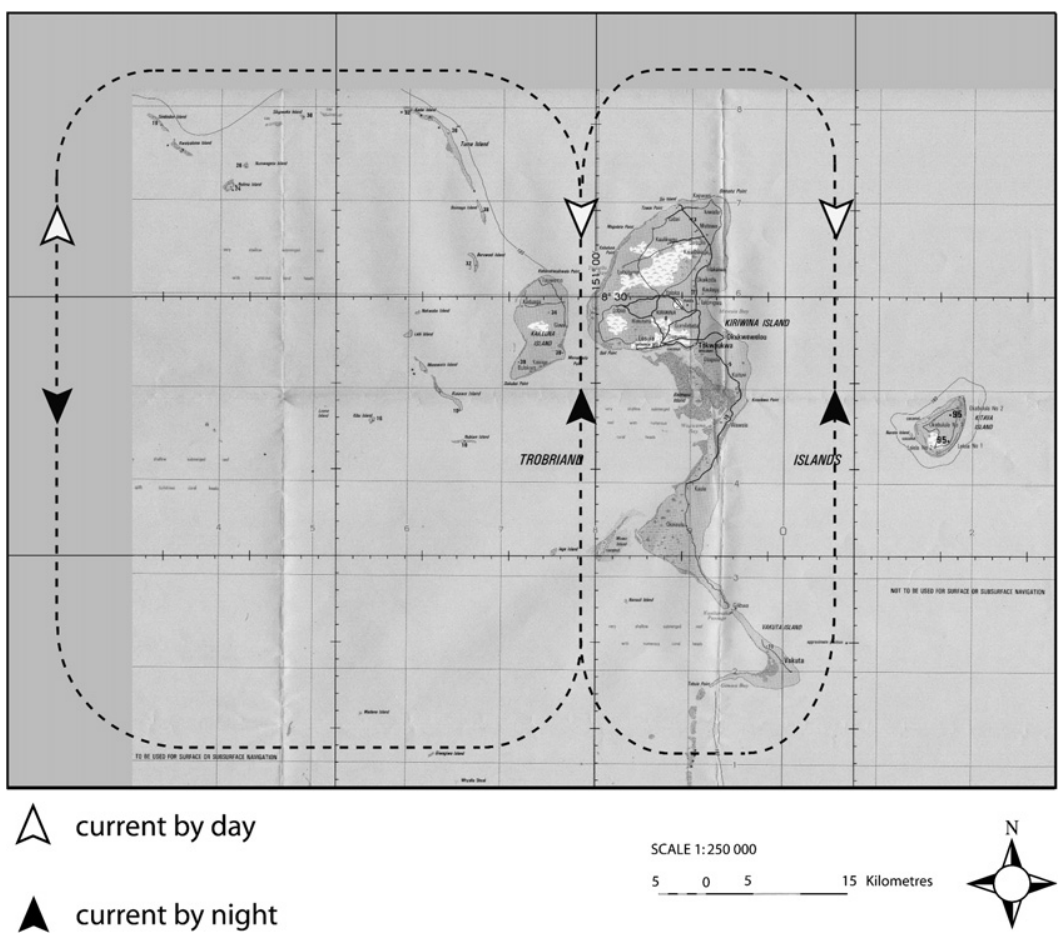

Fig. 3. Currents in the sea surrounding the Trobriand Islands.

Other hydrology terms that I could document with the help of my consultants refer to two rivers and some freshwater wells on Kaile'una Island (see Fig. 5).

The name of the river that has its source in the swamp in the centre of Kaile'una Island and that flows out into the sea between Negwa point and Mamamada point in the south east of Kaile'una is called Uyanaki. My consultants explain this name with the following anecdote: Once there was a man who always boastingly shouted ula vavagi '(this is) my making', claiming that he was responsible for the many fish in this rivulet. Then people started to refer to this river with the phrase ula vavagi - and then corrupted it into Uyanaki.

The other river has its source also in the swamp in the centre of Kaile'una Island but flows out into the sea between Lovakakata point and Budabuda point in the west of Kaile'una Island. Its name is Ludobu. My consultants say this name is an archaic variant of the noun kabokariga '(place) where one dies' and explain it with the fact that there are many dangerous crocodiles close to the mouth of this river. The general word for river is $v a y a$, and the Trobriand Islanders distinguish between its source $u$ 'una 'root', 'source', 'origin' and its mouth matala 'its head'. The term for a small course of running water is yeyelu 'creek'. The word for 'swamp' is dumia; the swamp on Kaile'una Island does not have a specific place name.

Quite generally the noun phrase sopi bwena 'good water' refers to freshwater wells. My consultants mentioned the following names of freshwater wells that are all located in the vicinity of Tauwema village (see Fig. 5): 


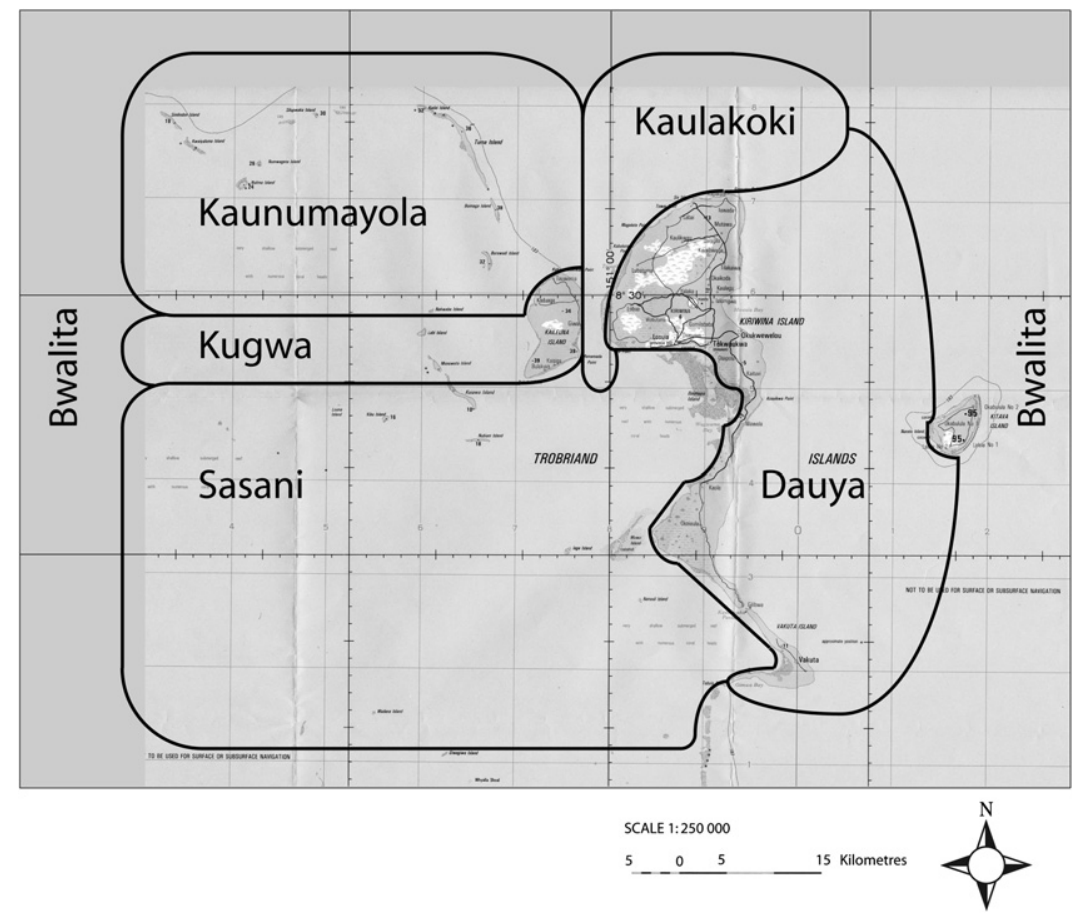

Fig. 4. Named parts of the sea around the Trobriand Islands.

According to my consultants Buyaku is a corruption of the phrase o buyagu in the garden'. This freshwater well actually is inside a nice grotto which is said to be the home of Namsasela, a spirit woman who may harm people if they disturb her or do not respect her. Therefore not many people dare to take a bath in the Buyaku grotto which is still in the bush but close to the beach about $1 \mathrm{~km}$ northeast of Tauwema.

Tuyabwau is the name of a freshwater well which a man called Moyabwau dug out and - using some coral stones - constructed a kind of natural bath-tub around it and who then named the well and the bathing place Tuyabwau. In the afternoon the men of Tauwema usually go there to have a bath. The place is at the beach about $200 \mathrm{~m}$ southwest of Tauwema.

Kauyakum is the name of another fresh water well at the beach about $600 \mathrm{~m}$ southwest of Tauwema. According to my consultants the name is a corruption of the phrase kauya lakum 'bag (of the) crab(s)' and it refers to the fact that there are many crabs in the vicinity of this well.

Bugei is the name of a beautiful grotto filled with freshwater southwest of Tauwema in the bush, about $300 \mathrm{~m}$ away from the shore. The fresh water comes directly from the freshwater bulb below the coral island; therefore, the height of the water inside the grotto is dependent on the tides. The terms dubwadebula, katukwaka, and vavatu refer to caves and grottos of different size; however, all caves ${ }^{10}$ or grottos filled with freshwater have a specific place name. My consultants explained the name Bugei with the following anec-

${ }^{10}$ The term for 'cave' is lagi. 


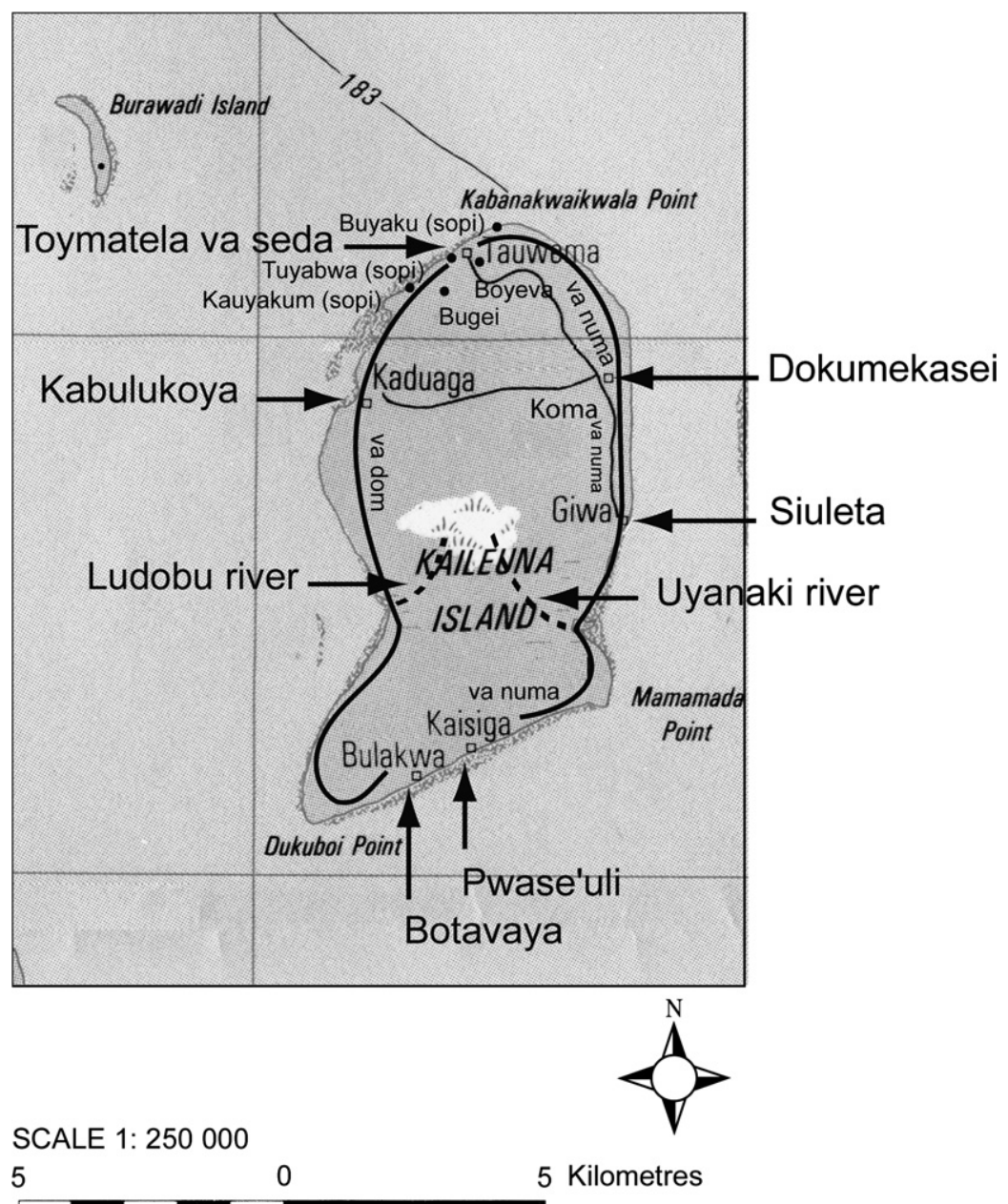

Fig. 5. Names of rivers, fresh water wells, and reef-channels on Kaile'una Island.

dote: The water there is rather cold; therefore many people are said to have answered invitations to go and have a bath with someone in the grotto as follows (using the subjectmarker of the dual inclusive as a defocusing and impersonalizing device of very polite language use): ${ }^{11}$

Lagela

Today

bata-kaya

Fut.Dual.incl-have.a.bath

'Today one will stay (here, but) in two days one will go and have a bath.'

11 Abbreviations used: Fut(ure), incl(usive).

bata-sisu
Fut.Dual.incl-stay bogiu

day.after.tomorrow

bata-la

Fut.Dual.incl-go 
This answer was then shortened into bogiu 'the day after tomorrow' and then corrupted into Bugei as the name of the (cold) water grotto. It is the bathing place of unmarried girls and young and old men, and usually groups of girls and groups of men bathe there together (but not in mixed groups).

Married women bathe at the water well about $50 \mathrm{~m}$ south of the village centre from which they also collect excellent drinking water that is not brackish at all. This well is called Boyeva. My consultants told me that this is a corrupted form of the expression bwena eva 'good - it comes to (us)'.

The data presented in this section represent all the hydrology-related terms and place names I could find for Kilivila so far.

\subsection{Coral reefs, corals, reef-channels, islands, and island points}

As we come from the sea to the land we first have to pass the reef. The noun that refers to reefs in general is manakapu; however, this term is rather rarely used. In everyday conversation speakers seem to prefer using the terms that differentiate between dead and living coral reefs. The Kilivila noun dakuna refers to dead coral reefs, coral stone heads, and coral and other stones. The term lai refers to reefs and coral heads with corals that are still alive; lai is also the general term for corals. The Trobriand Islanders differentiate between a number of different coral species. I could document the following terms for various types of coral, although I have not been able to identify the species: kebwa, lada, nada, pwaka, sibata, yalui. I am convinced that this list is far from being complete. It remains to mention here that the edge of the reef is called deyaga and the reef plateau is called leliga.

In order to land on an island sailors or paddlers have to find channels in the reef. The general term for reef-channel is kalikeda; reef-channels that lead to the villages on Kaile'una ${ }^{12}$ have specific names. Fig. 5 presents these reef-channels.

The reef-channel of Tauwema is called Toymatela va seda. According to my consultants toymatela is an archaic form of toyamata 'guardian', va seda 'to the tropical almond tree (Terminalia catappa)' is the name of a part of Tauwema village; thus, the name of the reefchannel means 'guardian of the va seda village part (of Tauwema)'.

The reef-channel that leads through the reef to the path to Koma village (which is about $1 \mathrm{~km}$ inland from the sea shore) is called Dodumekasei. This is the name of a big stone at the beach, and there is a myth that is associated with this coral formation. Unfortunately my consultants do not know this myth.

The reef-channel of Giwa is called Siuleta. According to my consultants this name is a corruption of the phrase esi'uli luleta 'he spatters his sister'. It may refer to an anecdotal event, but my consultants are unable to explain why this reef-channel was given this name.

The reef-channel of Kaisiga is called Pwase'uli, which is the name of a song cycle that is sung during the harvest ritual. These songs are called wosi milamala 'songs of the harvest ritual' (see Senft, 1985, 2003; Eibl-Eibesfeldt and Senft, 1991). Unfortunately I could not document this song cycle so far.

The reef-channel of Bulakwa is called Botovaya. My consultants explain this name as an archaic expression meaning sena bwalita 'much sea' or, rather, 'high waves'.

${ }^{12}$ I will explain the village names in Section 3.3 below, see also Fig. 8. 
Finally, the reef-channel of Kaduwaga is called Kabulukoya which literally translates as 'point (of a) mountain'; however, there is no mountain ${ }^{13}$ in the vicinity of Kaduwaga and my consultants explained the name as actually meaning kabulu kweveaka 'difficult (heavy) point'. This is indeed a proper and quite self-explaining name for this reef-channel which is very crooked and ends at a reef plateau from which one has to walk for about $200 \mathrm{~m}$ through slimy mud to the village.

The reef-channels just mentioned are the most important channels for the people living on Kaile'una. However, my consultants told me that there are other reef-channels in the vicinity of the island points that allow canoe crews to land if necessary.

The general Kilivila name for island is simla. All the Trobriand Islands are named; however, my informants could only tell me that Kaile'una means u'ula valu '(the) reason for villages' and that Simsim is a reduced reduplicated form of the noun simla 'island'. All the islands have points, most of which are named. The general noun in Kilivila that refers to such a point is kabulu (also kabunu, kabulula). Fig. 6 presents the names of all the points of Kaile'una Island. However, before we look at the points of Kaile'una I would like to note the following: the eastern coast of Kaile'una - from Tauwema in the north close to Kaisiga in the south - is the part where the coral reefs of the island rise between 2 and $3 \mathrm{~m}$ out of the sea. At low tide one can walk on top of the reef plateau in front of the rising reef, but at high tide the sea clashes towards these relatively high reefs. The coral ridge - called rebwaga - gradually flattens out towards the west side of the island and is covered with bush. The reefy coast of the island is called va numa 'to the reef', 'in the direction of the reef' (see Fig. 5). ${ }^{14}$ The coast at the west of Kaile'una - from close to Bulakwa in the southwest to close to Tauwema in the north - has large sandy beaches and there is hardly any difference in elevation anymore between land and sea-shore. This lagoon-like coast of the island is called va dom 'to the lagoon', 'in the direction of the lagoon' (see Fig. 5). Let us now have a look at Fig. 6 that presents the names of all the points of Kaile'una Island.

The northernmost point of Kaile'una, about $1 \mathrm{~km}$ northeast of Tauwema, is called Kabukukwevala. ${ }^{15}$ The name is explained as a corruption of the phrase kabulu kweveaka 'difficult point'. At this point there is a reef formation that is called waga emilidakuna 'the canoe petrified', and there is a mythical story that describes the origin of this formation (see Senft, 1995).

The next point southeast is called Dabweta, a shortened form of the possessed noun dabwetasi 'our wreathes of flowers'. Close to this point there are many frangipani trees the flowers of which are used to make floral wreathes.

The name of Bwabuga point was explained by my consultants with the verb ebwabusi 'they cut (trees for canoes)' there. Thus it refers to the traditional cutting place for trees used to construct the big masawa type canoes (see Malinowski, 1922).

The point southeast of Koma is called Oganagwa. According to my consultants this name refers to trees that are called ganau in Kilivila (I could not verify its proper botanical name). Thus, the point's name can be glossed as 'at the ganau trees'.

\footnotetext{
${ }^{13}$ I would like to add here that the term koya refers both to 'mountain' and 'hill'; the term sakala refers to 'valley'.

${ }^{14}$ Malinowski (1935, vol. II, p. 81) refers to this topographical concept as wa lum and glosses it as 'in the open sea'.

${ }^{15}$ Note that the name of this point is spelled Kabanakwaikwala on the map. However, the proper Kilivila name of the point is Kabukukwevala.
} 


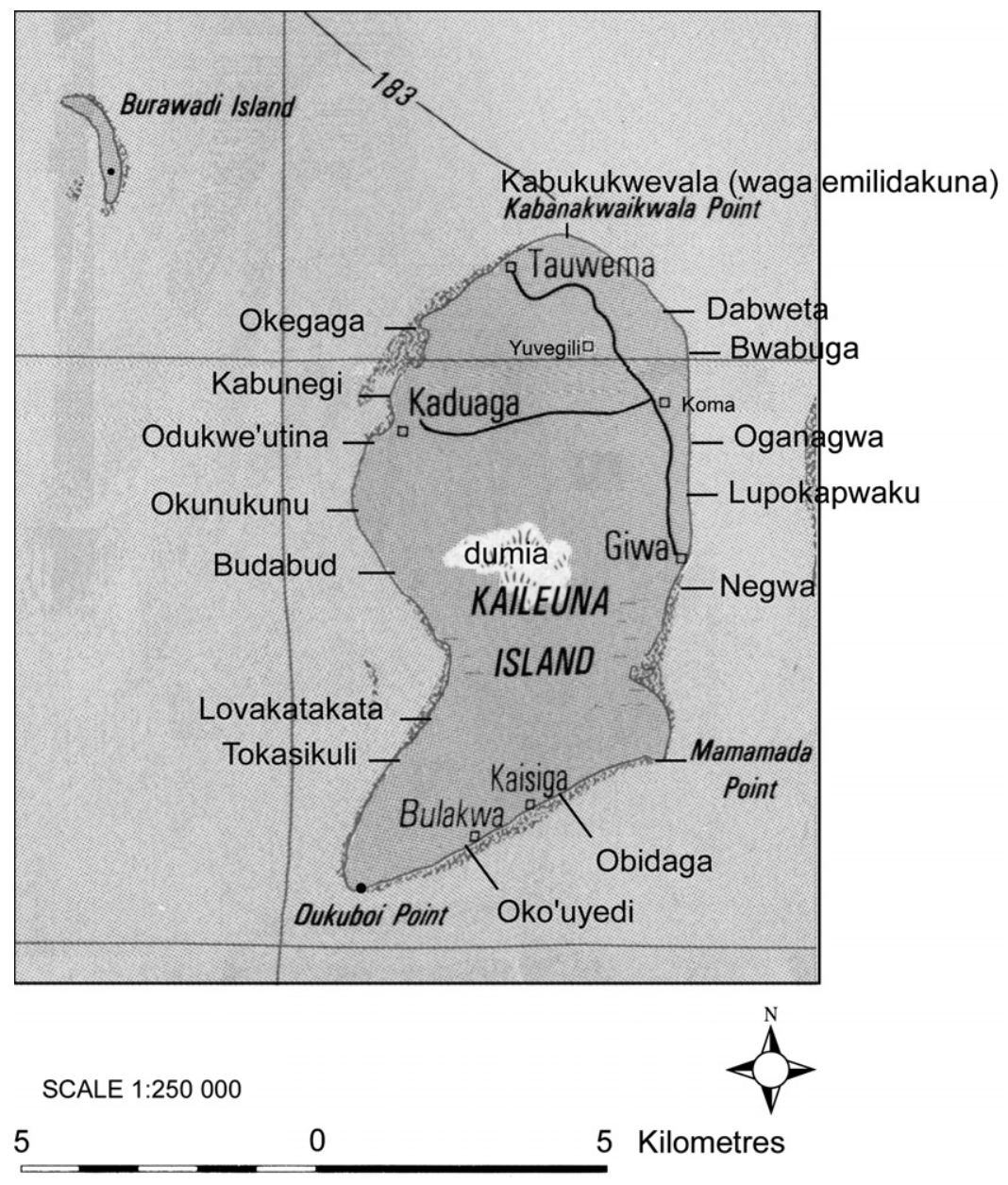

Fig. 6. Names of points of Kaile'una Island.

Between Koma and Giwa is the point called Lupokapwaku. My consultants explained this name with the phrase kapwaku elupisi which translates as 'the seagulls jump'.

The name of the next point south of Giwa is also related to seagulls. Negwa is a variant of the noun nigwa 'nest (of seagulls)'.

The name of Mamamada point was explained to me as an archaic form of the exclamation $o$ sanana which can be glossed 'Oh, sea urchins!'. There are indeed many sea urchins in the vicinity of this point.

Southwest of this point, close to Kaisiga, is the point Obidaga. According to my consultants this name is a corrupted form of the phrase $o$ mi daga which can be glossed as 'at our ladder'. My consultants are unable to explain why this point was given this name.

Further southwest, close to Bulakwa, is a point called Oko'uyedi. This name can be glossed as 'at the uyedi shell'. In the vicinity of this point there are many shells of the family Muricidae, especially Chicoreus ramosus and Chicoreus torrefactus (see Hinton, n.d., p. 26). These shells are called uyedi in Kilivila. 
The southernmost point of Kaile'una is called Dukuboi. My consultants explain this name as a variant of the exclamation $o$ boil which translates as 'oh, a heron!'. While herons are indeed common here, the point is especially known for the presence of big sharks.

Tokasikuli is the name of the point that is north of Dukuboi point at the west-coast of Kaile'una. This point is reminiscent of a man called Tokasikuli who was exiled from Kaisiga by the inhabitants of this village because he was covered in ulcers.

Further north is Lovakakata point. According to my consultants this name is a corruption of the sentence lova ekakata kova which means 'yesterday it burned the fire'. My consultants cannot give the reason for this name.

The next point up north on the west coast is called Budabuda. This name is a variant of the reduplicated noun boda boda 'group (of people) group (of people)' and refers to the fact that this is the place where people from Kaduwaga and people from Kaisiga used to meet each other.

Okunukunu - the name of the next point north of Budabuda - refers to the following anecdote: At this point a young man is said to have watched a girl bathing, and when she got out of the sea he saw for the first time the pubic hair of a girl and exclaimed: o kunu 'oh hair!'.

The point southwest of Kaduwaga is called Odukwe'utina. According to my consultants this name is an archaic variant of the phrase o kabulula 'at the point', but they do not know why this point was given this name.

The point northwest of Kaduwaga is called Kabunegi. According to my consultants this name is a variant of the archaic noun kabonaga which means 'thoughts' or 'thinking' (nanamsa in present day Kilivila), but again they cannot provide an explanation why this point has been named this way.

The last point that is named on Kaile'una is the point that lies north of Kaduwaga, just between Kaduwaga and Tauwema. According to my consultants its name Okegaga refers to the archaic phrase o kegaga which can be glossed as 'very heavy' (sena kweveaka in present day Kilivila). Again my consultants are unable to explain why this point was given this name.

\subsection{Types of soil, gardens, villages and village parts}

In the previous subsection, I mentioned that one has to walk through slimy mud to reach Kaduwaga from the sea via its reef-channel. The Kilivila word for 'mud' is podidiveta. This soil is unsuitable for planting. However, the beaches in front of the villages Tauwema, Giwa, Kaisiga, and Bulakwa are sandy and white - and the Kilivila word for 'sand' - kenakenua - can indeed also be used to refer to beach. The other term for beach is kwadeva. The name for cultivable garden soil is pwepwaya; this noun as well as the noun kabimwaya refer to fertile soil in general. It is on this soil where the bush - laodila - grows. The term laodila is also used to refer to rainforest and wood. Specific types of fertile soil are also differentiated: galaluwa refers to a black, heavy and dry kind of fertile soil (suitable for all crops), butuma refers to a light red soil (not suitable for taro but for yam), kawala refers to a fertile black soil (suitable for most crops) that is found in the coral gardens (that have the same name as the coral ridge, namely rebwaga), sawewa refers to the soil found in the deep holes of the rebwaga (suitable for yam, especially for the long kuvi type of yam), mo' $a$ is a dry light soil in the vicinity of coral gardens (good for yam), malala refers to stony soil (good for yam) and kwedikidakuna refers to very stony soil (only suit- 
able for some crops). Soils that are not suited for cultivation are podidiveta 'mud', kenakenua 'sand', dumia 'swamp', and pasa 'brackish mud in mangrove swamps', kovalawa 'sandy beaches between mangroves', and dakuna 'stones', 'rock'. Finally, the soil where the villages are located is called bidivalu 'soil of the village' (see also Malinowski, 1935, vol. II, pp. 79-87).

Fig. 7 presents the various garden portions, the cultivable pieces of land that belong to the villages on Kaile'una. These garden portions are called kwabila.

The name of the garden land that belongs to Tauwema is Gubale'i. This is the name of a flower that is said to have crept up a stick that one of the men of Tauwema once carelessly stuck into the ground. I cannot provide the correct botanical name of this flower.

Kavola - a variant of the noun kivola - is the name of the garden land that belongs to the inhabitants of Koma. The name means '(a) find'.

The name of the garden land that belongs to the people of Giwa is Lovebida. This was the former name of Giwa. My consultants do not know why this garden was given this name.

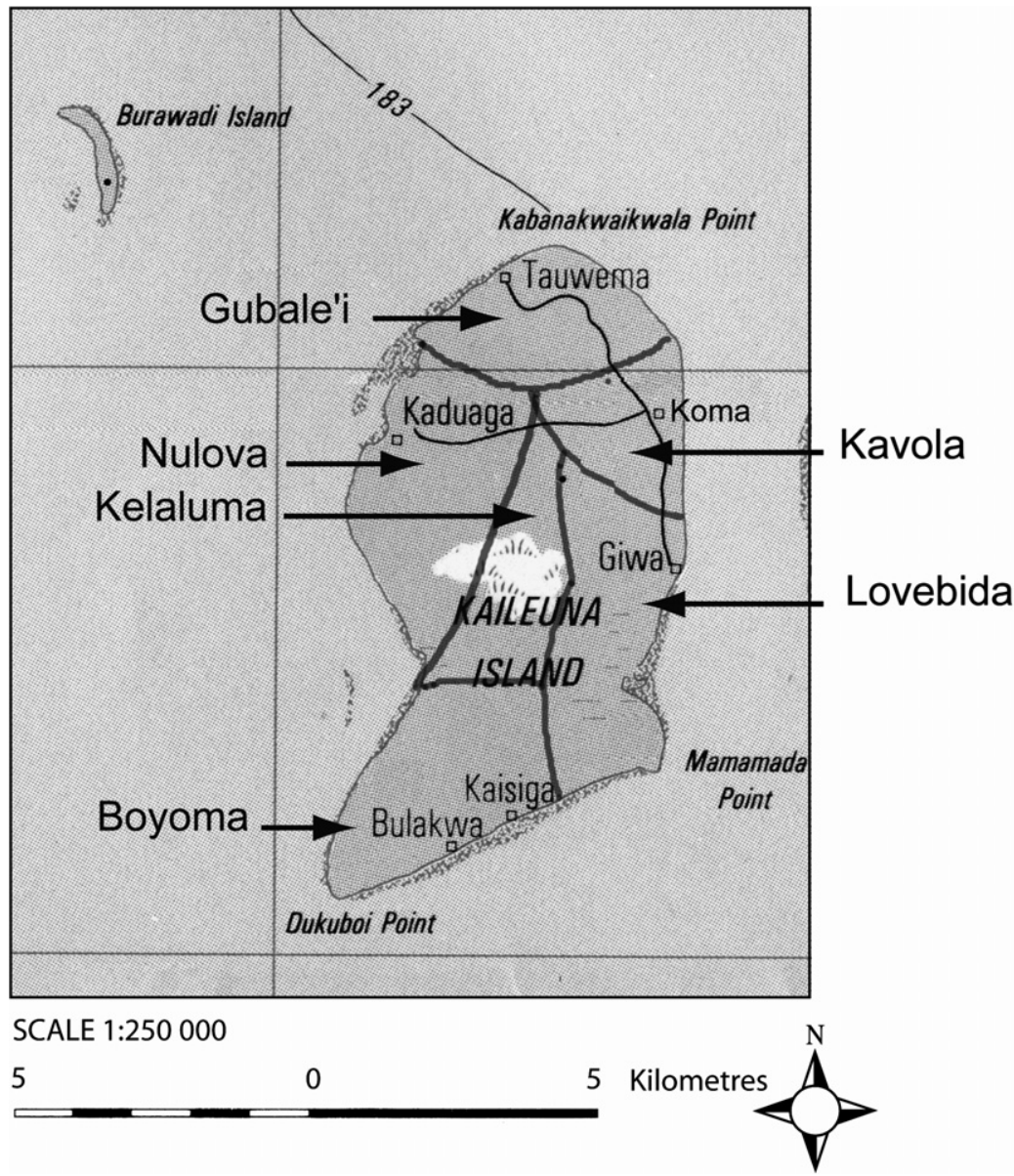

Fig. 7. Names of garden portions on Kaile'una Island. 
The garden land that belongs to the villages Bulakwa and Kaisiga is called Boyoma this is the name of a well within this garden portion. Again, my consultants do not know why this garden was given this name.

Nulova is the name of the garden land that belongs to the inhabitants of Kaduwaga. My consultants explain this name as an archaic form of the verbal expression ele'isi 'they throw it away'. However, they do not know why this garden was given this name.

The garden land around the central swampy area of the island is called Kelaluma. My consultants told me that this noun refers to 'garden land with freshwater wells in it'. Both the inhabitants of Kaduwaga and Tauwema can cultivate this garden portion.

The boundaries between these garden portions are well known; they are called karige' $i$. The general unspecified term for garden(s) is bagula. The garden land as a whole is subdivided in smaller garden plots; these plots are called baleko, and the borders between these plots are called tukulumwala. Personal specific garden plots that are under cultivation are called buyagu. The expression bagulela refers to a garden with monoculture. The noun kemata refers to a big newly cultivated garden. The noun kemgwa refers to a medium-sized garden and the noun kapuputala refers to one small garden. The noun ligaba refers to an old garden. The noun makavasisiva refers to a garden where no garden-magic was performed. The noun mowa refers to a swampy garden. The noun rebwaga refers to a typical coral garden that is very difficult to cultivate. And the noun tapopwa refers to a taro-garden (see also Malinowski, 1935, vol. II, pp. 79-87; Senft, 1986, p. 495).

Fig. 8 presents the names of the villages on Kaile'una Island.

According to my consultants the name of the village Tauwema is a corruption of the phrase tau ema '(a) man came'; it refers to Mobiliuya, the former chief of the inland village Yuvegili who came to the place where Tauwema is now, decided to abandon the unhealthy inland village and founded Tauwema at the beginning of the last century.

The name of the village Koma is a shortened form of the verbal expression akoma ' $\mathrm{I}$ eat'. My consultants have no explanation as to why this village was given this name.

The name of the village Giwa is a variant of the noun giu 'spittle'; it refers to the coral stones called dadagi that are about $100 \mathrm{~m}$ north of the village. These coral stones are full of holes, and at high tide the seawater is 'spitting' through these holes.

The name of the village Kaisiga refers to an exclamation of one of its founding inhabitants who realized that his yam had rotten away. He exclaimed $k a$, esigi 'oh, it is rotten' (the equivalent expression in present day Kilivila would be kaula egaga 'the yam has rotten away').

The name of the village Bulakwa refers to the verbal expression elaki it cleans the rubbish; it refers to the fact that at high tide the sea cleans all the rubbish that was deposited at the relatively small shore of this village.

The name of the biggest village of Kaile'una, Kaduwaga is a corruption of the exclamation ka waga! 'oh, a canoe!'. My consultants do not know why this village was given this name.

The villages Kaduwaga, Tauwema, Giwa and Koma are subdivided into village sectors; these sectors are called kabuluyuvela or katuposula; many of them have special names. The village sectors of Tauwema are called $\mathrm{Va}$ seda 'towards the tropical almond tree (Terminalia catappa)', Oluvala 'in the middle', Va yayu 'towards the yayu tree' and Valu kwevau 'the new village'. Moreover, all villages have a village ground or a village square that is referred to generically as baku. 

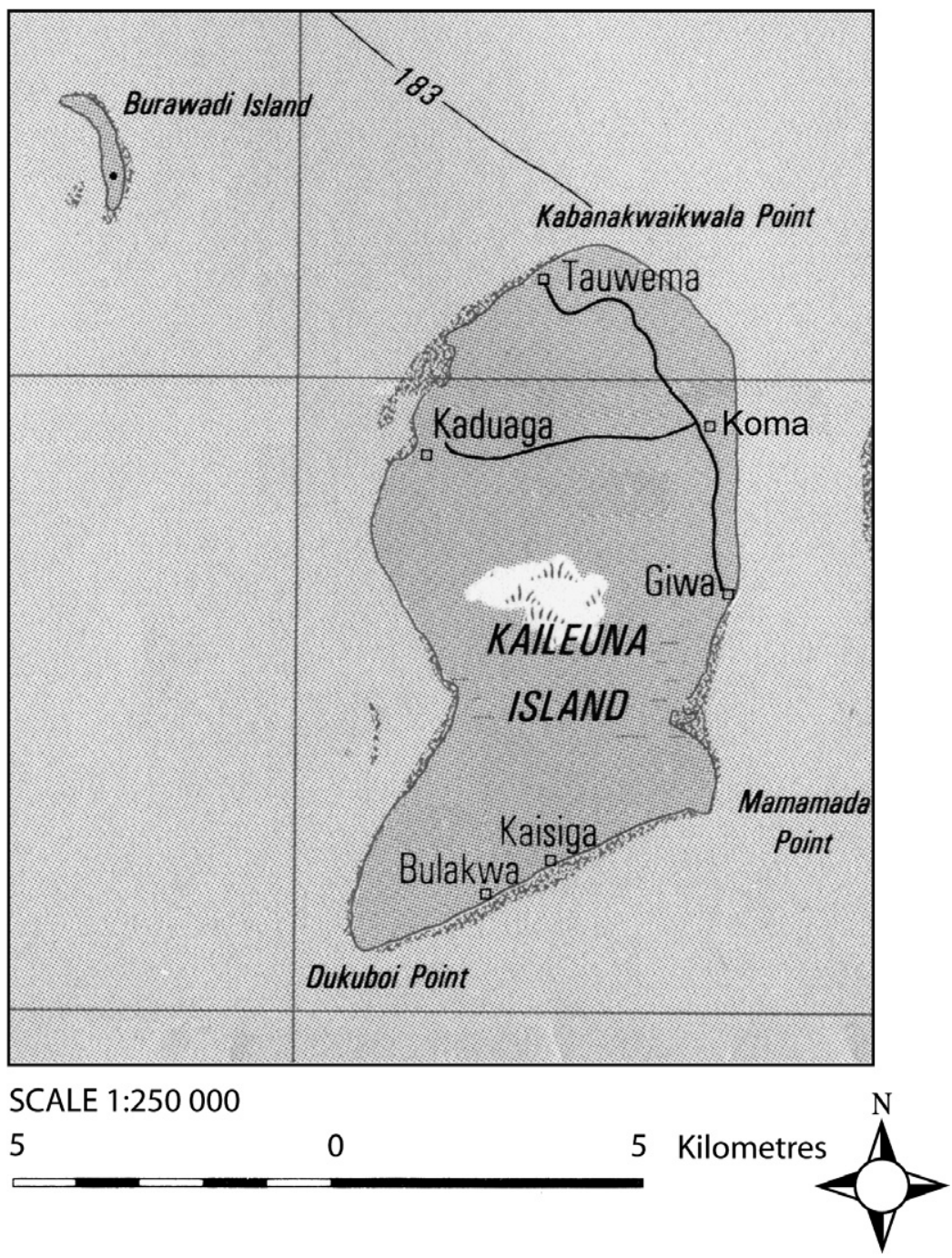

Fig. 8. Names of the villages on Kaile'una Island.

\subsection{Kilivila place names in the Kaile'una subset - a summary}

The landscape terms and place names that I have been able to elicit during the last 23 years of my field research on the Trobriand Islands constitute only a part of the Kaile'una subset of these terms. Despite the fact that the inventory of landscape terms and place names presented here is not exhaustive, the terms listed are reasonably representative of the types of Kilivila landscape terms and place names.

In this subsection, I summarize the names found for villages, gardens, wells, reef-channels, and points on Kaile'una and present them in a table that mentions the sources of the respective place names. As we have seen, the place names refer to events (gone by or 
typically expected), landmarks, states, places, things, villages, songs, people, activities, anecdotes, food, animals, plants, and stones. Table 1 summarizes the Kilivila subset of place names and presents a first attempt to typologically classify and categorize them. In the final section of the paper, I will discuss this proposed typology of place names and the kind of landscape terms found and presented in Section 3.

\section{Summing up: What does it all mean?}

In the previous section, I presented the Kai'leuna subset of Kilivila place names and landscape terms. As to the latter we noticed that they consist of both simple and complex forms. Usually landscape terms are (common) nouns - this holds for the terms for currents, reefs, corals, coastlines, and for different types of soils and gardens; however, we also find prepositional phrases, namely locatives (for referring to sea areas), and directionals (for referring to coast lines). All these landscape terms constitute specific taxonomies. The fact that the Trobriand Islanders have landscape terms for sea parts, currents, reefs and corals on the one hand and for different types of soils and gardens on the other reflects the conceptual importance of these domains for these islanders who are not only skilled seafarers and excellent navigators but also first and foremost gardeners.

Landscape terms do not typically enter into lexical relations with terms outside their domain and they are seldom targets of metaphor. Although I pointed out in Section 3.1 above that the mouth of a river is called matala 'its head' (by the way, the same term is also used to refer to the 'top of a mountain' - matala koya), I think that this should not be overestimated in the Kilivila case. In Kilivila only occasional body part terms are used to refer to landscape features, and these terms are grammaticalized in such a way that they are almost desemanticized. However, I would like to point out that the human body and its parts play an important role in the expression of spatial relationships in general; we find highly interesting grammaticalization processes of body part terms that are used to express these spatial relationships in the languages of the world (see, e.g., Bowden, 1992; Senft, 1994, 1997, pp. 18ff).

With the exception of one noun phrase (for referring to a reef-channel) and one sentence (for referring to a reef formation) all the place names presented above are single (though not necessarily monomorphemic) words; however, as illustrated above, their meaning can actually be quite complex. They refer to events, landmarks, states, places, things, villages, songs, people, activities, anecdotes, food, animals, plants, and stones. Most place names are far from being semantically transparent; on the contrary, they are highly culture specific and their origin is quite surprising and puzzling at times. ${ }^{16}$ Like landscape terms the place names also constitute specific taxonomies (for water wells, reefchannels, islands, island points, and villages); there is no hierarchic structure whatsoever observable. We have seen, though, that place names rarely include the landscape terms as such in them. However, in general they map quite well onto each other denotationally. With the exception of terms for corals and reefs, where I could not get proper names of coral and reef formations (although I know that there are such names for formations in the Solomon Sea), Kilivila has

\footnotetext{
${ }^{16}$ However, compare, for example, the meaning of the name of the point Okunukunu with the etymology David Lodge provides in part iv of his 1995 novel Therapy for the name of the village Labacolla in the vicinity of Santiago de Compostela (see German edition: Lodge, 2000, p. 366).
} 
Table 1

Kilivila place names (the Kaile'una subset) and their sources

\begin{tabular}{|c|c|c|c|c|}
\hline $\begin{array}{l}\text { Source of } \\
\text { place name }\end{array}$ & $\begin{array}{l}\text { Sea parts, wells, rivers, } \\
\text { and reef-channels }\end{array}$ & Points & Gardens & Islands and villages \\
\hline Events & $\begin{array}{l}\text { Siuleta 'he spatters his } \\
\text { sister' }\end{array}$ & $\begin{array}{l}\text { Lupokapwaku '(where) } \\
\text { the seagulls jump' } \\
\text { Lovakakata 'yesterday } \\
\text { the fire burned' }\end{array}$ & $\begin{array}{l}\text { Kavola 'find' } \\
\text { Nulova 'they throw } \\
\text { it away' }\end{array}$ & $\begin{array}{l}\text { Tauwema 'a man } \\
\text { came' }\end{array}$ \\
\hline Landmarks & $\begin{array}{l}\text { Toymatela va seda } \\
\text { 'guardian of the va seda } \\
\text { village part' }\end{array}$ & $\begin{array}{l}\text { Negwa 'nest of seagulls' } \\
\text { Budabuda 'place where } \\
\text { groups of people } \\
\text { (meet)' Odukwe 'utina } \\
\text { 'at the point' }\end{array}$ & $\begin{array}{l}\text { Boyoma name of a } \\
\text { well in this garden } \\
\text { Kelaluma 'garden } \\
\text { land with fresh } \\
\text { water wells' }\end{array}$ & $\begin{array}{l}\text { 'Giwa spittle' (close } \\
\text { to the village the } \\
\text { water 'spits' through } \\
\text { holes in the reef at } \\
\text { high tide) }\end{array}$ \\
\hline States & $\begin{array}{l}\text { Dum/Dam 'waves beat' } \\
\text { Kugwa 'first' } \\
\text { Kaunamayola 'very old' } \\
\text { Boyeva 'good it comes' } \\
\text { Botovaya 'high waves' } \\
\text { Kabulukoya 'difficult } \\
\text { point' }\end{array}$ & $\begin{array}{l}\text { Kabukukwevala } \\
\text { 'difficult point' } \\
\text { Okegaga 'heavy point' }\end{array}$ & & $\begin{array}{l}\text { Kaile'una 'reason for } \\
\text { villages' Kaisiga 'oh } \\
\text { it is rotten' }\end{array}$ \\
\hline Places & $\begin{array}{l}\text { Ludobu 'where one dies' } \\
\text { Buyaku 'in the garden' }\end{array}$ & $\begin{array}{l}\text { Bwabuga 'cutting place } \\
\text { for trees' }\end{array}$ & & $\begin{array}{l}\text { Simsim 'island' } \\
\text { Oluvala 'in the } \\
\text { middle' }\end{array}$ \\
\hline Things & Sasani 'rattles' & $\begin{array}{l}\text { Obidaga 'at your } \\
\text { ladder' }\end{array}$ & & $\begin{array}{l}\text { Kaduwaga }=k a \\
\text { waga 'oh canoes' }\end{array}$ \\
\hline Villages & $\begin{array}{l}\text { Toymatela Vaseda } \\
\text { 'guardian of Va seda' }\end{array}$ & & $\begin{array}{l}\text { Lovebida former } \\
\text { name of the village } \\
\text { Giwa }\end{array}$ & $\begin{array}{l}\text { Valu kwevau 'new } \\
\text { village' }\end{array}$ \\
\hline Songs & Pwase uli name of a song & & & \\
\hline People & $\begin{array}{l}\text { Tuyabwau name coined by } \\
\text { the digger of the well } \\
\text { Moyabwau }\end{array}$ & $\begin{array}{l}\text { Tokasikuli name of a } \\
\text { man with many ulcers }\end{array}$ & & \\
\hline Activities & & $\begin{array}{l}\text { Kabunegi 'thoughts, } \\
\text { thinking' }\end{array}$ & & $\begin{array}{l}\text { Bulakwa'(the sea) } \\
\text { cleans the rubbish' }\end{array}$ \\
\hline Anecdotes & $\begin{array}{l}\text { Bugei 'the day after } \\
\text { tomorrow' (answer people } \\
\text { gave when invited to bath } \\
\text { in the cold sweet water } \\
\text { grotto) Uyanaki 'my } \\
\text { making' (man boasting he } \\
\text { was responsible for the } \\
\text { fish in the river) }\end{array}$ & $\begin{array}{l}\text { Okunukunu 'oh, hair!' } \\
\text { (exclamation of a } \\
\text { young man when he } \\
\text { first saw a girl's pubic } \\
\text { hair) }\end{array}$ & & \\
\hline Food & $\begin{array}{l}\text { Kaulakoki 'food oh } \\
\text { indeed' }\end{array}$ & & & \\
\hline Animals & $\begin{array}{l}\text { Dauya 'triton shell' } \\
\text { Kauyakum 'bag of crabs' }\end{array}$ & $\begin{array}{l}\text { Mamamada 'oh, sea } \\
\text { urchins!' Oko'uyedi 'at } \\
\text { the uyedi shell' Dukuboi } \\
\text { 'oh, a heron' }\end{array}$ & & \\
\hline Plants & & $\begin{array}{l}\text { Dabweta 'our wreathes } \\
\text { of flowers' Oganagwa } \\
\text { 'at the ganau trees' }\end{array}$ & $\begin{array}{l}\text { Gubale'i name of a } \\
\text { flower }\end{array}$ & $\begin{array}{l}\text { Va seda 'towards the } \\
\text { almond tree' } V a \\
\text { yayu 'towards the } \\
\text { yayu tree' }\end{array}$ \\
\hline Stones & $\begin{array}{l}\text { Dodumekasi (stone close } \\
\text { to reef-channel) }\end{array}$ & & & \\
\hline
\end{tabular}


- a generic term for the sea and proper names for sea areas

- a generic term for current and proper names for currents

- a generic term for freshwater well and proper names for freshwater wells

- a generic term for reef-channel and proper names for the channels

- a generic term for point and proper names for the points

- a generic term for garden and proper names for garden lands

Like place names in other languages and cultures the Kilivila place names convey "cultural knowledge about the environment" (Kuipers, 1984, p. 465) and "signal something about the significant characteristics of the place" (Merlan, 2001,p. 370). However, they do much more, like, for example, telling tales - to mention just one of many more fascinating functions.

The place names presented here appear to contradict some of the assertions of colleagues who seek "semantic universals in place-name systems" (Hunn, 1996, p. 3). However, I would like to point out that the Kilivila data presented here suggest at least the following speculation - which may lead to a probably universal claim with respect to research on landscape terms and place names in general: landscape terms seem to be indicative of the geographical domains that are conceptually important for the speakers who coined them - thus, simply a brief look at the Kilivila lexicon would have revealed that 'sea' and 'soil for gardens' play an important role in the life of the Trobriand Islanders - and place names, once understood, reveal much with respect to the culture, the characteristics, and the culture-specific humour of the speakers who created them.

\section{Acknowledgements}

I want to thank the National and Provincial Governments in Papua New Guinea, the Institute for PNG Studies - especially Don Niles, and the National Research Institute especially James Robins, for their assistance with, and permission for, my research projects. I express my great gratitude to the people of the Trobriand Islands, and above all the inhabitants of Tauwema and my consultants for their hospitality, friendship, and patient cooperation over all these years. Without their help, none of my work on the Kilivila language and the Trobriand culture would have been possible. Last but not least I would like to thank Niclas Burenhult, Steve Levinson, Andrew Turk and two anonymous referees for critical comments on earlier versions of this paper.

\section{References}

Bach, A., 1952. Deutsche Namenkunde. Einleitung. Zur Laut- und Formenlehre, Wortfügung, -bildung und -bedeutung der deutschen Personennamen. 2., stark erweiterte Auflage. Karl Winter, Heidelberg.

Bach, A., 1953a. Deutsche Namenkunde. Die deutschen Personennamen in geschichtlicher, geographischer, soziologischer und psychologischer Betrachtung. 2., stark erweiterte Auflage. Karl Winter, Heidelberg.

Bach, A., 1953b. Deutsche Namenkunde. Einleitung. Zur Laut- und Formenlehre, zur Satzfügung, Wortbildung und -bedeutung der deutschen Ortsnamen. Karl Winter, Heidelberg.

Bach, A., 1954. Deutsche Namenkunde. Die deutschen Ortsnamen in geschichtlicher, geographischer, soziologischer und psychologischer Betrachtung. Ortsnamenforschung im Dienste anderer Wissenschaften. Karl Winter, Heidelberg.

Basso, K.H., 1984. Stalking with stories: names, places, and moral narratives among the Western Apache. In: Plattner, S. (Ed.), Text, Play, and Story: The Construction and Reconstruction of Self and Society. 1983 
Proceedings of the American Ethnological Society. American Ethnological Society, Washington, DC, pp. 1955.

Boas, F., 1934. Geographical Names of the Kwakiutl Indians. Columbia University Contribution to Anthropology No. 20. Columbia University Press, New York.

Bowden, J., 1992. Behind the Preposition: Grammaticalisation of Locatives in Oceanic Languages. Pacific Linguistics, Canberra.

Bright, W., 1998a. California Place Names, by Erwin G. Gudde, 4th revised edition by W. Bright. University of California Press, Berkeley.

Bright, W., 1998b. 1500 California Place Names. University of California Press, Berkeley.

Bright, W., 2004. Native American Placenames of the United States. University of Oklahoma Press, Norman.

Broderick, G., 1994. Placenames of the Isle of Man. Volume 1: Sheading of Glenfaba. Max Niemeyer, Tübingen.

Broderick, G., 1995. Placenames of the Isle of Man. Volume 2: Sheading of Michael. Max Niemeyer, Tübingen.

Broderick, G., 1997. Placenames of the Isle of Man. Volume 3: Sheading of Ayre. Max Niemeyer, Tübingen.

Broderick, G., 1999. Placenames of the Isle of Man. Volume 4: Sheading of Garff. Max Niemeyer, Tübingen.

Broderick, G., 2000. Placenames of the Isle of Man. Volume 5: Sheading of Middle. Max Niemeyer, Tübingen.

Broderick, G., 2002. Placenames of the Isle of Man. Volume 6: Sheading of Rushen. Max Niemeyer, Tübingen.

Broderick, G., 2005. Placenames of the Isle of Man. Volume 7: Sheading of Douglas and Appendices. Max Niemeyer, Tübingen.

Christmann, E., 1937a. Von Wotans- und Donarsbergen in der Pfalz. Saarpfälzische Abhandlungen 1, 5-17.

Christmann, E., 1937b. Ramsen und Stumpfwald. Was bedeuten ihre Namen. Saarpfälzische Abhandlungen 1, 61-66.

Christmann, E., 1938. Beiträge zur Flurnamenforschung im Gau Saarpfalz. Mit 8 Abbildungen. Flurnamen Bayerns, Reihe IX, Heft 1. München, Oldenbourg, pp. 1-52.

Christmann, E., 1940. Vom Namen der Madenburg in der Pfalz. Saarpfälzische Abhandlungen 4, 287-293.

Christmann, E., 1968. Die Siedlungsnamen der Pfalz, Teil I. Verlag der Pfälzischen Gesellschaft zur Förderung der Wissenschaften, Speyer.

Cowell, A., Moss Sr., A., 2003. Arapaho place names in Colorado: form and function, language and culture. Anthropological Linguistics 45, 349-389.

Dominy, M., 1995. Toponymy: positionality and containment of New Zealand High Country Stations. Landscape Review 2, 16-41.

Eibl-Eibesfeldt, I., Senft, G., 1991. Trobriander (Papua-Neu-Guinea, Trobriand-Inseln, Kaile'una) Tänze zur Einleitung des Erntefeier-Rituals. Film E 3129. Trobriander (Papua-Neuguinea, Trobriand-Inseln, Kiriwina) Ausschnitte aus einem Erntefesttanz. Film E 3130. Publikationen zu Wissenschaftlichen Filmen. Sektion Ethnologie. 17. Institut für den Wissenschaftlichen Film IWF, Göttingen, pp. 1-17.

Ernst, P., Hausner, I., Schuster, E., Wiesinger, P. (Eds.), 2002. Ortsnamen und Siedlungsgeschichte - Akten des Symposiums in Wien von 28-30.9.2000. Winter, Heidelberg.

Förstemann, E.W., 1863. Die deutschen Ortsnamen. Nordhausen.

Hercus, L., Hodges, F., Simpson, J. (Eds.), 2002. The Land Is a Map: Placenames of Indigenous Origin in Australia. Pandanus Books, Canberra.

Hinton, A., n.d. Guide to Shells of Papua New Guinea. Robert Brown and Associates, Port Moresby.

Hosokawa, K., 2003. Yolngumatha Ethnographic Lexicon: with Particular Reference to Toponyms Associated with Creation Stories and Related Cultural and Environmental Terms. Endangered Languages of the Pacific RIM, Osaka.

Hunn, E., 1996. Columbia Plateau Indian place names: what can they teach us. Journal of Linguistic Anthropology 6, 3-26.

Kari, J., 1989. Some principles of Alaskan Athabaskan toponymic knowledge. In: Key, M.R., Hoenigswald, H. (Eds.), General and Amerindian Ethnolinguistics. Mouton de Gruyter, Berlin, pp. 129-150.

Kuipers, J.C., 1984. Place, Names, and Authority in Weyéwa Ritual Speech. Language in Society 13, 455466.

Lodge, D., 1995. Therapy. Secker and Warburg, London (German edition: 2000. Therapie. Diana, München).

Lounsbury, F., 1960. Iroquois Place Names. University of the State of New York, State Education Department, Albany.

Malinowski, B., 1922. Argonauts of the Western Pacific. An Account of Native Enterprise and Adventure in the Archipelagoes of Melanesian New Guinea. Routledge, London.

Malinowski, B., 1935. Coral Gardens and Their Magic. Vol. I: The Description of Gardening. Vol. II: The Language of Magic and Gardening. George Allen and Unwin, London. 
Marck, J., 1994. Proto micronesian terms for the physical environment. In: Pawley, A.K., Ross, M.D. (Eds.), Austronesian Terminologies: Continuity and Change. Pacific Linguistics, Canberra, pp. 301-328.

Mark, D.M., Turk, A.G., 2003. Landscape categories in Yindjibarndi: ontology, environment, and language. In: Kuhn, W., Worboys, M., Timpf, S. (Eds.), Spatial Information Theory: Foundations of Geographic Information Science. Springer-Verlag, Berlin, pp. 28-45.

Merlan, F., 2001. Form and context in Jawoyn placenames. In: Simpson, J., Nash, D., Laughren, M., Austin, P., Alpher, B. (Eds.), Forty Years On: Ken Hale and Australian Languages. Pacific Linguistics, Canberra, pp. 367-383.

Mithun, M., 1984. Principles of Naming in Mohawk. In: Tooker, E (Ed.), Naming Systems. Proceedings of the American Ethnological Society 4, pp. 40-53.

Ross, M.D., 1988. Proto Oceanic and the Austronesian Languages of Western Melanesia. Pacific Linguistics, Canberra.

Schützeichel, R. (Ed.), 1985. Giessener Flurnamen-Kolloquium : 1-4 Oktober 1984. Schriftenreihe: Beiträge zur Namenforschung, Beihefte. N.F. 23. Winter, Heidelberg.

Senft, G., 1982. Sprachliche Varietät und Variation im Sprachverhalten Kaiserslauterer Metallarbeiter Untersuchungen zu ihrer Begrenzung, Beschreibung und Bewertung. Peter Lang, Bern, Frankfurt am Main.

Senft, G., 1985. Trauer auf Trobriand - eine ethnologisch/linguistische Fallstudie. Anthropos 80, 471-492.

Senft, G., 1986. Kilivila - The Language of the Trobriand Islanders. Mouton de Gruyter, Berlin.

Senft, G., 1994. Grammaticalisation of body-part terms in Kilivila. Language and Linguistics in Melanesia 25, 98-99.

Senft, G., 1995. Crime and custom. auf den Trobriand-Inseln: Der Fall Tokurasi. Anthropos 90, 17-25.

Senft, G., 1997. Introduction. In: Senft, G. (Ed.), Referring to Space - Studies in Austronesian and Papuan Languages. Clarendon Press, Oxford, pp. 1-38.

Senft, G., 1999. Bronislaw Kasper Malinowski. In: Verschueren, J., Östman, J.-O., Blommaert, J. (Eds.), Handbook of Pragmatics. Supplement 1998. John Benjamins, Amsterdam, pp. 1-10.

Senft, G., 2003. Wosi Milamala - Weisen von Liebe und Tod auf den Trobriand Inseln. In: Bobrowski, I. (Ed.), Anabasis - Prace Ofiarowane Professor Krystynie Pisarkowej. LEXIS, Kraków, pp. 289-295.

Smith, B., Mark, D.M., 1999. Ontology with human subjects testing: an empirical investigation of geographic categories. American Journal of Economics and Sociology 58, 245-272.

Smith, B., Mark, D.M., 2001. Geographic categories: an ontological investigation. International Journal of Geographic Information Science 15, 591-612.

Tindale, N.B., 1962. Geographical knowledge of the Kaiadilt People of Bentick Island, Queensland. Records of the South Australian Museum 14, 259-296.

Urmes, D., 2004. Handbuch der geographischen Namen. Marixverlag, Wiesbaden.

Young, M., 2004. Malinowski: Odyssee of an Anthropologist 1884-1920. Yale University Press, New Haven and London. 